\title{
PERKEMBANGAN KESENIAN GONDANG DI KECAMATAN PAGERAGEUNG KABUPATEN TASIKMALAYA
}

\author{
Oleh Enden Irma R. \\ Balai Pelestarian Sejarah dan Nilai Tradisional Bandung \\ Jln. Cinambo No. 136 Ujungberung Bandung \\ Email: bpsntbandung@ymail.com
}

\begin{abstract}
Abstrak
Jawa Barat, salah satu provinsi di Indonesia yang cukup kaya dengan kesenian tradisional dengan berbagai bentuk dan jenisnya. Salah satu kesenian tersebut adalah Seni Tradisional Gondang yang tetap terpelihara keberadaannya di wilayah Kecamatan Pagerageung Kabupaten Tasikmalaya Jawa Barat.

Secara historis, Seni Gondang dikembangkan di daerah Jawa Barat oleh para leluhur pesyiar agama Islam. Salah satu contoh dari tokoh tersebut adalah Kangjeng Syeh Syarif Hidayatullah atau yang dikenal dengan Sunan Gunung Jati. Bentuk seni ini digunakan sebagai alat untuk menyebarkan agama Isam di daerah Jawa Barat.

Pola pertunjukan Kesenian Gondang dari dahulu sampai sekarang sudah banyak mengalami perubahan. Pada mulanya pertunjukan Kesenian Gondang hanya menggunakan lisung dan halu serta pakaian yang dikenakan oleh para pemainnya pun sangat sederhana dan tidak disertai dengan gerak tari lainnya. Adapun pada saat ini Kesenian Gondang itu selain ada penambahan waditra (alat), juga pakaian para pemainnya pun dikemas lebih menarik disertai dengan gerak tari yang indah.
\end{abstract}

Kata Kunci: Gondang, seni tradisional, Pagerageung.

\section{Abstract}

West Java is one Provinces in Indonesia which is rich of traditional arts with various kinds and shapes. One of the arts is traditional Gondang which is still preserved in Pagerageung Sub District of Tasikmalaya in West Java.

Historically, the art was developed by Moslem ancestors in West Java. One of the example is Geat Syech Syarif Hidayatullah or mostly well known as Sunan Gunung Jati. Such kind of art is used to spray Islam in West Java.

The pattern of Gondang art is changing most of the time. To begin with, Gondang show was only using lisung and halu. Beside, the players use very asample cloth and without any movments. But at the present time, there are some additional tools, and the players used interesting clothes and danced beautifully.

Keywords: Gondang, traditional art, Pagerageung.

\section{A. Pendahuluan}

Jawa Barat, salah satu provinsi di Indonesia yang cukup kaya dengan kesenian tradisionalnya, dengan berbagai bentuk, jenis, dan penyajiannya.
Keanekaragaman kesenian tradisional dari bentuk dan jenis keseniannya, di masing-masing daerah berbeda. Salah satu peran dan fungsi jenis kesenian tradisional yang sekarang masih tetap 
dipelihara keberadaannya adalah Seni Tradisional Gondang di wilayah Kecamatan Pagerageung Kabupaten Tasikmalaya.

Kesenian tradisional masyarakat Provinsi Jawa Barat, keberadaanya dapat dikatakan sudah kurang mendapat perhatian dari masyarakatnya. Hal ini tak terkecuali pada Kesenian Gondang, selain keberadaannya cukup memprihatinkan, juga memiliki tampilan yang agak berbeda dengan kesenian tradisional lainnya. Selain itu Kesenian Kesenian Gondang ini memiliki ciri khas tersendiri. Oleh karena itu, untuk mengetahui sejarah keberadaan Kesenian Gondang tersebut, penulis akan mengadakan penelitian yang berfokus pada masalah:

1. Bagaimana keberadaan Kesenian Gondang pada masyarakat kecamatan Pagerageung Kabupaten Tasikmalaya?

2. Bagaimana bentuk tampilan Kesenian Gondang di daerah tersebut?

3. Apa fungsi Kesenian Gondang pada masyarakat Kecamatan Pagerageung?

4. Bagaimana perkembangan kesenian itu di Kecamatan Pagerageung?

Untuk lebih jelasnya sebuah penelitian perlu adanya sebuah tujuan. Adapun tujuan dalam penelitian ini adalah sebagai berikut:

Untuk mengetahui bagaimana keberadaan Kesenian Gondang di Kecamatan Pagerageung Kabupaten Tasikmalaya; bagaimana pengaruh Kesenian Gondang di Kecamatan Pagerageung Kabupaten Tasikmalaya; untuk mengetahui bagaimanan peran dan fungsi Kesenian Gondang di Kecamatan Pagerageung Kabupaten Tasikmalaya; untuk mengetahui bagaimana nilai-nilai budaya yang terkandung dalam Kesenian Gondang di Kecamatan Pagerageung Kabupaten Tasikmalaya.

Keberadaan Kesenian Gondang di kecamatan ini cakupannya cukup luas, oleh karena itu penulis akan menguraikan beberapa permasalahannya, yaitu :

Menguraikan tentang keberadaan Kesenian Gondang, mulai sejarah, bentuk dan perubahan-perubahan. Hal ini akan melibatkan masyarakat sebagai pemilik Kesenian Gondang tersebut. Menguraikan tentang pengaruh kesenian Gondang, adat kepercayaan tentang kekuatan seni tersebut dalam implementasi masyarakat atau sejauh mana pengaruh Kesenian Gondang tersebut dalam kehidupan sehari-hari. Menguraikan jenis dan fungsi Kesenian Gondang.

Adapun pengambilan lokasi penelitian di daerah Kecamatan Pagerageung ini, karena daerah ini merupakan daerah yang masih mempertahankan keberadaan Kesenian Gondang. Penelitian ini menggunakan metode deskriptif analisis, artinya mendeskripsikan atau menjelaskan tentang keberadaan data pada saat diadakan penelitian. Dengan kata lain, menggambarkan keberadaan Kesenian Gondang beserta nilai-nilai budayanya yang ada di Kecamatan Pagerageung Kabupaten Tasikmalaya. Adapun pengambilan datanya melalui wawancara mendalam pada sejumlah informan, pengamatan (observasi), dan studi pustaka.

\section{B. Hasil dan Bahasan}

Di antara kesenian tradisi yang berkembang di daerah Jawa Barat, Kesenian Gondang tumbuh dan berkembang hamper di setiap daerah di Jawa Barat, seperti di Kabupaten Tasikmalaya dan beberapa daerah lainnya.

Secara historis, Seni Gondang dikembangkan di daerah Jawa Barat oleh para leluhur pesyiar agama Islam. Salah satu contoh dari tokoh tersebut adalah Kangjeng Syeh Syarif Hidayatulloh atau yang dikenal dengan Sunan Gunung Jati. Bentuk seni ini digunakan sebagai alat untuk menyebarkan agama Islam di daerah Jawa Barat. 
Melihat kenyataan sekarang, Kesenian Gondang sudah banyak mengalami perubahan, baik dari segi pertunjukan maupun dari segi isi. Perubahan ini kemungkinan disesuaikan dengan perkembangan peradaban masyarakat, khususnya masyarakat Jawa Barat. Melihat kenyataan tersebut, Kesenian Gondang itu dapat digolongkan ke dalam dua jenis, yaitu jenis kesenian Gondang buhun dan jenis kesenian Gondang Wanda anyar.

Keberadaan Kesenian Gondang Buhun ini diperkirakan hidup dan berkembang pada jaman penjajahan atau dapat dikatakan jaman sebelum kemerdekaan. Adapun kesenian jenis Gondang Wanda Anyar, keberadaannya setelah bangsa Indonesia merdeka. Hal ini ditandai dengan perubahan pada kesenian tersebut baik bentuk maupun isinya.

Kesenian Gondang sebelum kemerdekaan disebut dengan Kesenian Gondang Buhun. Yang menjadi ciri dari kesenian ini dilihat dari segi bentuknya terdiri atas tiga unsur, yaitu:

1. Lisung (lesung);

2. Halu (alu);

3. Kakawihan (lalaguan).

Bila dilihat dari segi kostum, khususnya kostum perempuan yaitu menggunakan kemben (merupakan pakaian yang hanya digunakan sebatas dada). Menggunakan kemben ini agar lebih leluasa dan lebih praktis. Adapun untuk kostum laki-laki menggunakan kostum pangsi (pakaian hitam dan celana panjang hitam dengan ukuran yang cukup lebar) dan sarung.

Untuk pelaksanaan pertunjukan Kesenian Gondang Buhun, biasanya dilaksanakan pada berbagai kegiatan yang berhubungan dengan kebiasaan masyarakat, baik kegiatan yang berhubungan dengan kegiatan ritual keagamaan maupun kegiatan ritual kemasyarakatan. Kegiatan Kesenian Gondang dalam kegiatan ritual keagamaan biasanya dilaksanakan pada waktu akan datangnya bulan puasa, lebaran, Rajaban, dan Muludan. Untuk pelaksanaan ritual keagamaan ini tidak seluruh wilayah, tetapi hanya sebagian wilayah saja.

Adapun pelaksanaan Kesenian Gondang dalam acara tradisi kemasyarakatan, yaitu dilaksanakan pada mapag panen (menyambut panen raya), perayaan pengantin sunat, dan ketika datangnya samagaha (gerhana bulan). Sehubungan dengan pelaksanaan pertunjukan Kesenian Gondang tersebut, Kesenian Gondang Buhun memiliki fungsi sebagai berikut:

1. Sebagai tangara (informasi); Sebagai bewara ketika masyarakat di sekitar lokasi wilayah akan mengadakan suatu perayaan (hajatan).

2. Sebagai galintang;

Sebagai tanda ketika ada yang meninggal pada hari Sabtu. Pada saat golintang ini pertunjukan Seni Gondang hanya menabuh lisung dan halu (tutunggulan) saja tidak disertai dengan kakawihan.

3. Sebagai penghormatan; Sebagai pernghormatan kepada Dewi Sri ketika musim panen tiba.

4. Sebagai nutukeun panganten sunat;

Biasa diadakan dalam acara khitanan.

5. Sebagai simbol ketika datangnya samagaha (gerhana).

Fungsi simbol ini bentuk pertunjukannya sama dengan fungsi galintang, yaitu hanya memukul lisung dengan halu saja tidak disertai dengan kakawihan.

Bila dilihat dari segi waditra yang digunakan dalam Kesenian Gondang Buhun hanya terdiri atas waditra (alat) lisung dan halu. Waditra lisung memiliki fungsi sebagai alat tutunggulan atau 
tabuhan, sedangkan halu sebagai alat untuk ketukan yang pukulannya disesuaikan dengan laras yang sudah dijadikan pakeman (kebiasaan) dalam Kesenian Gondang tersebut.

Kesenian Gondang ini pada awal keberadaan hanya memiliki tiga unsur, yaitu adanya lisung, halu dan kakawihan. Adapun pada saat ini Kesenian Gondang ini telah mengalami perubahan, yaitu dengan adanya unsur penabuh waditra. Yang dimaksud dengan waditra tersebut adalah adanya kecapi, suling, gendang dan goong. Penambahan waditra tersebut masih bertahan hingga saat ini. Adapun unsur penambahan lainnya adalah ada pada unsur kakawihan. Perubahan pada unsur kakawihan ini cukup kreatif, cukup banyak mengalami perubahan, baik pada lirik maupun pada larasnya. Adanya perubahan tersebut berdampak pada nama jenis Kesenian Gondang. Nama jenis Kesenian Gondang sebelum kemerdekaan disebuat Gondang Buhun, sedangkan setelah kemerdekaan disebut Kesenian Wanda Anyar.

\section{Alat-alat dalam Kesenian Gondang}

Sesuai dengan namanya, Seni Gondang ini menggunakan alat lesung yang terbuat dari kayu berbentuk seperti perahu berukuran kecil dengan panjang sekitar \pm 2 meter dan lebar 0,5 meter. Kemudian ada pula alat halu (alat penumbuk padi), yang terbuat dari kayu berbentuk bulat panjang sekitar $\pm 1,5-2$ meter. Dan yang terakhir ada juga nyiru/tampah (tempat membersihkan beras), yang terbuat dari anyaman bambu yang berbentuk bulat dengan diameter \pm 0,5 meter.

Waditra lainnya dalam Kesenian Gondang ini adalah kecapi, gendang, suling, dan goong. Untuk kecapi sendiri dimainkan dengan cara dipetik oleh jari tangan kanan dan tangan kiri, sedangkan gendang dimainkan dengan cara dipukul menggunakan tangan yang digunakan untuk memegang waditra yang akan dimainkan.

\section{Kesenian Gondang Tri Buana}

Sebagai salah satu bentuk seni tradisi yang ada di Jawa Barat, Kesenian Gondang di Kabupaten Tasikmalaya dalam penampilan karyanya banyak mengalami perkembangan dan perubahan dari bentuk aslinya. Pengembangan dan perubahan tersebut tampak pada isi, bentuk, waditra yang digunakan, dan tata penyajian.

Grup Seni Gondang yang masih ada di Desa Nanggewer yaitu Seni Gondang Tri Buana, yang telah berdiri sejak 1981 dan dipimpin secara turun temurun. Dan saat ini generasi terakhir yang memimpin kesenian ini adalah Ibu Eva Maria Ulfah.

Sebagaimana dikemukakan oleh Ibu Eva (selaku pengasuh) dari Grup Seni Gondang Tri Buana, yang berkembang di Kecamatan Pagerageung Kabupaten Tasikmalaya adalah jenis Gondang Buhun dan Gondang Wanda Anyar.

\section{Gondang Tradisional}

Gondang buhun ini dalam penyajiannya biasanya masih bersifat tradisional, artinya dari segi alat maupun cara memainkannya masih bersifat tradisional, yaitu hanya menggunakan alat-alat musik yang terdiri atas lesung, halu, dan nyiru.

\section{Gondang Wanda Anyar}

Dalam Gondang ini digunakan alat-alat yang lebih lengkap serta maju dari Gondang Buhun, baik dari alat maupun cara bermainnya. Alat-alat yang biasa digunakan dalam kesenian ini tetap memakai alat tradisional seperti lesung, halu, dan nyiru, hanya saja pada Gondang ini telah dilengkapi dengan kecapi, gendang, suling, dan goong. 


\section{Waditra dalam Kesenian Gondang Tri Buana}

Seni Gondang merupakan salah satu kesenian yang menggunakan waditra petik dan waditra tatabeuhan.

\section{a. Waditra Gondang}

Mengenai waditra Gondang, Kubarsah menjelaskan bahwa: Waditra Gondang terbuat dari bahan baku kayu, biasa dipergunakan kayu nangka. Waditra Gondang dimainkan dengan cara dipetik.

\section{b. Waditra Tatabeuhan}

Waditra tatabeuhan terbuat dari bahan baku kayu, biasa dipergunakan kayu sawo dan kenanga. Adapun kulit yang digunakan adalah kulit kambing dan kelinci. Bahan perlengkapan lainnya dipergunakan cat, rotan, paku, dan rantai. (1995: 82).

\section{Bentuk Pertunjukan}

Menurut Iik Setiawan dan Ismet Ruchimat dalam buku "Seni Karawitan", menyebutkan bahwa : Dilihat dari cara penyajiannya karawitan Sunda dapat dikelompokkan menjadi tiga jenis, yaitu sekar, karawitan gending, dan karawitan campuran " (1996: 29).

a. Karawitan Sekar

Yang dimaksud Karawitan Sekar adalah karawitan yang didominasi oleh unsur suara manusia atau disebut pula sekar dalam istilah musik disebut vokal.

b. Karawitan Gending

Karawitan Gending adalah karawitan yang pada penyajiannya dititikberatkan pada penonjolan serta penggolongan unsur-unsur gending. Lagu-lagu yang dimainkan pada Karawitan Gending dibentuk dari gabungan beberapa waditra dan bentuknya biasa kita sebut instrumentalia.

c. Karawitan Sekar Gending
Karawitan Sekar Gending adalah bentuk karawitan yang dihasilkan dari pengolahan gabungan antara sekar dan gending. Karawitan ini disebut pula dengan istilah Karawitan Campuran. Pada penyajiannya, kedudukan gending berfungsi sebagai pengiring sekar/nyanyian (1996: 33).

Dari uraian di atas, dapat kita simpulkan bahwa setiap jenis kesenian, baik itu buhun maupun wanda anyar mempunyai bentuk penyajian yang berbeda, disesuaikan dengan jenis keseniannya.

Adapun bentuk penyajian dari Seni Gondang Tri Buana adalah termasuk pada bentuk penyajian karawitan sekar gending atau karawitan campuran. Dalam penyajiannya seni Gondang ini terdiri dari sekaran atau nyanyian (vocal) dan gending (instrumen) sebagai pengiring.

\section{Masa Perkembang Kesenian Gondang Tri Buana}

Kesenian Gondang Tri Buana pada awal perkembangannya mengalami berbagai tantangan dan hambatan. Tantangan dan hambatan tersebut bukan terletak pada waditra yang digunakannya, melainkan tertumpu pada para pemain. Kesulitan pemain ini disebabkan oleh waktu yang dimiliki oleh para pemain, sebab rata-rata para pemain ini berstatus sebagai buruh, pedagang, dan petani. Untuk lebih jelasnya mengenai perkembangan tersebut akan diuraikan berikut ini:

\section{a. Awal Keberadaan Kesenian Gondang di Desa Nanggewer}

Sebagai seni pertunjukan rakyat biasanya Kesenian Gondang di Desa Nanggewer ini biasanya hanya dipertunjukkan pada saat menjelang panen raya tiba. Kebiasaan pertunjukan tersebut seiring dengan perkembangan jaman. Terjadilah perubahan waktu untuk pertunjukan, yaitu pada waktu peringatan 
hari besar dan pada penyelenggaraan tradisi hajatan ataupun pada saat pelaksanaan kegiatan-kegiatan ritual keagamaan. Apabila kita memperhatikan Kesenian Gondang, baik dilihat dari pertunjukan maupun makna kesenian tersebut, maka dapat memiliki ciri sebagai berikut :

(1) Kesenian Gondang terdiri atas tiga unsur, yaitu waditra, pemain, dan kakawihan;

(2) Kesenian Gondang dilaksanakan pada kegiatan-kegiatan yang berhubungan dengan tradisi kemasyarakatan dan pada kegiatankegiatan hari bersejarah/ besar;

(3) Tujuan lebih dipentingkan daripada estetis; dan

(4) Diperlukan busana yang khas.

Dari uraian di atas dapat kita lihat bahwa pada masa lalu Kesenian Gondang tidak bisa dipergelarkan pada setiap saat, tetapi dipergelarkan pada waktu-waktu tertentu dan biasanya selalu dilakukan pada malam hari. Pada masa ini pertunjukan Kesenian Gondang tidak bisa didokumentasikan, baik dalam rekaman kaset maupun rekaman gambar.

\section{b. Awal Berdirinya Kesenian Gondang Tribuana}

Ibu Eva mengatakan, pada masa sekarang Seni Gondang dugunakan pula pada dalam acara-acara pernukahan, khitanan serta acara peringatan hari kemerdekaan Republik Indonesia. Sekarang pertunjukan Seni Gondang tidak hanya dilakukan pada malam hari saja, tapi juga dapat dilakukan pada siang hari disesuaikan dengan permintaan dari pihak penyelenggara. Pada masa sekarang pertunjukan Seni Gondang sudah bisa didokumentasikan, baik berupa rekaman kaset maupun gambar.

Supaya seni tradisional rakyat (Kesenian Gondang) tidak menjadi punah, maka para seniman dari Seni Gondang pada umumnya tidak membiarkan seni tradisional tersebut menjadi beku. Untuk itu setiap generasi terus berusaha untuk melakukan inovasi terhadap Seni Gondang. Para seniman secara sadar, kreatif, dan selektif memasukkan ide-ide baru ke dalam Seni Gondang dengan tujuan untuk memberikan nafas baru yang dapat mendekatkan Seni Gondang mencapai keadaan yang sesuai dengan perkembangan jaman serta sesuai dengan tuntutan kebutuhan masyarakat modern.

Seni Gondang pada masa sekarang pada penyajiannya sudah dapat didokumentasikan, baik itu dalam bentuk rekaman kaset ataupun dalam bentuk gambar.

Berdasarkan uraian mengenai perkembangan Seni Gondang pada masa dulu dan sekarang terdapat perbedaan dan pengembangan tata cara penyajian Seni Gondang, antara lain :

(1) Pada acara ritual masa dulu pertunjukan Seni Gondang tidak bisa dilakukan pada setiap saat karena harus memenuhi persyaratanpersyaratan tertentu, misalnya perhitungan waktu dan tempat pertunjukan, pemilihan pemain, busana, serta sesaji yang lengkap sehingga tidak keluar dari ketentuan yang telah ditetapkan. Adapun pada masa sekarang, walaupun pertunjukan pada acara ritual, Seni Gondang dapat dimainkan kapan saja (tidak diperlukan perhitungan untuk mencari waktu dan tempat yang tepat), bergantung pada permintaan masyarakat penyelenggara. Perlengkapan sesaji dalam pertunjukan Seni Gondang tidak selalu harus diadakan, bergantung pada kepercayaan penyelenggara.

(2) Pada masa dulu Seni Gondang selalu dipertunjukkan pada malam hari, tetapi pada masa kini bisa juga dipertunjukkan pada siang hari. 
(3) Pada masa dulu selalu dipertunjukkan pada acara-acara ritual, tetapi pada masa sekarang selain pada acara ritual bisa dipertunjukkan pula pada acara hiburan, baik dalam pernikahan, khitanan bahkan dalam peringatan kemerdekaan Republik Indonesia.

(4) Pada masa dulu belum dapat didokumentasikan, pada masa sekarang sudah dapat didokumentasikan baik, dalam bentuk kaset maupun gambar.

Seni Gondang Tri Buana yang dikelola oleh Ibu Eva saat ini merupakan salah satu Seni Gondang yang sangat terkenal di daerah Tasikmalaya, karena Seni Gondang ini sudah sering mengisi beberapa acara, baik berupa ngaruat (mengadakan selamatan untuk menolak balai), mitembeyan (memulai sesuatu), selamatan, pernikahan, khitanan, peringatan Maulid Nabi Muhammad Saw., Rajaban, peresmian (pembukaan) suatu gedung atau bangunan, juga pada acara peringatan ulang tahun kemerdekaan Republik Indonesia. Jumlah pemain dalam Kesenian Gondang terdiri atas tujuh orang laki-laki dan enam orang perempuan. Kemudian pakaian yang dikenakan untuk perempuan menggunakan kebaya, kain, dan selendang. Rambutnya sendiri menggunakan sanggul. Adapun untuk pemain laki-laki, biasanya menggunakan baju kampret dengan kepala meng-gunakan iket.

Dalam Kesenian Gondang ini biasanya penyanyinya harus mempunyai vokal yang baik serta seirama dengan music, karena di dalam Gondang terdapat kombinasi suara yang dinamakan vokal indung, yaitu penyanyi yang dianggap paling baik dalam segi suara maupun pengalaman dari pemain lainnya.

\section{Sistem Pewarisan}

Ibu Eva mengatakan, bahwa : Seni Gondang ngawitan didirikeun ku Bapa
Dedi Hermayadi taun 1981, teras diturunkeun ka Bapa Tata ti ngawitan taun 1990 dugi ka kiwari. Pernyataan Ibu Eva tersebut dapat diterjemahkan, bahwa Seni Gondang Tri Buana didirikan oleh Bapak Jaja pada tahun 1981 kemudian diturunkan pada Bapak Tata pada tahun 1990 sampai sekarang.

Sejak didirikan oleh Bapak Dedi Hermayadi pada tahun 1981 dan oleh bapak Tata pada tahun 1990 sampai sekarang, Seni Gondang Tri Buana sudah banyak mengalami kemajuan dan perkembangan dalam pertunjukannya, disesuaikan dengan perkembangan jaman dan tuntutan masyarakat modern.

Adapun peristiwa dalam hal penguasaan lagu-lagu dan tabuhan waditra Gondang pada generasi muda, walaupun tidak ada pembinaan secara khusus, mereka melakukan dengan cara membeo atau memberikan contoh nyanyian dan tabuhan waditra Gondang secara sedikit-sedikit dan perlahanlahan, sehingga dapat diikuti oleh generasi muda.

\section{Bentuk Penyajian Kesenian Gondang Tri Buana}

Dilihat dari bentuk penyajiannya, Seni Gondang Tri Buana termasuk bentuk penyajian Karawitan Sekar Gending atau disebut juga Karawitan Campuran, yang terdiri atas sekaran atau nyanyian (vokal) dan gending sebagai pengiring. Dalam hal ini salah seorang pemain bertindak sebagai dalang, menyanyikan lagu-lagu yang diambil dari kisah tentang Dewi Sri. Sementara yang lainnya hanya bertugas sebagai pemain atau nyangga yang mengiringi nyanyian tersebut. Lagu-lagu atau nyanyian (vokal) tersebut diiringi dengan tabuhan waditra Gondang sebagai pengiring. 


\section{Iringan dalam Kesenian Gondang Tri Buana}

Adapun waditra-waditra yang digunakan dalam pertunjukan Seni Gondang Tri Buana terdiri atas 4 (empat) buah Gondang dan satu buah dog-dog yang meliputi :

- Gondang kempring berfungsi untuk memberikan irama sesuai dengan tuntunan lagu;

- Gondang tempas berfungsi memberikan variasi irama dari gondang kempring;

- Gondang tojo berfungsi untuk mengisi bunyi antara gondang kempring dan gondang tempas;

- Gondang galimer berfungsi sebagai goong.

\section{Kakawihan dalam Kesenian Gondang Tri Buana}

Lagu yang disajikan dalam Seni Gondang Tri Buana dapat dilihat sebagai berikut :

Muja (memuja kepada sang hyang Sri)

Ampun sampurasun

Pun Ampun paralun

Rahayu kasuhun

Ahung, ahung, ahung ..

Pun ampun ka sang rumuhun

Ka batara, ka batari ...

Ka batari Sang Hyang Sri

Neda agung Sang Rumuhun

Neda pangjaring apsari

Pang jaring wibawa mukti

Gemah ripah repeh rapih

Kecapi (musik)

JIRO

(Mojang-mojang datang sambil membawa peralatan menumbuk padi, seperti halu, boboko, nyiru, dan lisung) sambil menyanyikan:

Dina iuh-iuh tanjung, dina kalangkang katapang deuh.
Mojang ngarumpul ngariung, nyangking halu rek ngagondang. Heunteu eureun sukan-sukan, dipirig kacapi suling.

Sumawur ngentrung kamanggung, hawar-hawar kabeh anggang deuh.

Kentrung lisung nu ngagondang,

ngahudang jiwa pejuang.

Hayu patandang berjuang.

Musik tutunggulan

(Jajaka datang sambil menyanyikan lagu)

Durirang duraring hahariringan (2x).

Gandang ngalengkahna, gending ngagedigna.

Siga menak padjadjaran (2x).

Awang-awang ngarawangan, alam padang lenglang kaya aling-aling.

Hawar-hawar sora lisung tutunggulan.

Moal boa para mojang keur ngagondang.

Hayu batur urang pada sukan-sukan.

Urang cacapkeun meungpeung aya kasempetan.

Urang ngintip mojang lenjang,

$n u$ garinding keur ngagondang.

(Mojang dan Jajaka saling bersahutan) Jajaka: Daek milih ka uing jajaka desa ... deuh gagah perceka, loba harta ...

Mojang: Lain nampik, lain sik-sik melik

Uing teu butuh nu kitu, teu hayang ka nu perceka.

Daek soteh ka jajaka warga nu sinatria.

Nyaah ka nagara jeung bangsana.

Jajaka: Duh teungteuingeun, nampik teh sapajodogan.

Akang da nu perceka, nyaah ka nusa jeung bangsa

(gelenyu ... Kecapi)

Jajaka: Ka uing mah asana

piraku mungpang,

deuh gandang pertengtang,

loba uang 
Mojang: Lain mungpang, lain

heunteu hayang.

(Mojang dan jajaka mengitari

Daek soteh ka warga RI.

Ngagem ka ibu pertiwi.

Micinta lemah cai, patriot nu sajati.

Ngagem pancasila nu sayakti.

Jajaka: Duh ... Akang pisan nu ku euis kapicangcam.

Akang ngagem pancasila.

Nyaah ka nusa jeung bangsa.

Mojang: Lamun bener anjeun

sinatria.

Rek nanya naon hartina pancasila.

Sok jawab ...

Jajaka: Ari panca lima.

Sila dasar keur nagara.

Harti pancasila lima dasar keur nagara.

(hei.........!!!!) Solale lale $2 x$ solale $6 x$

..............waowaowae

Mojang: Dulang tinande $2 x$

Abdi kumaha keresa

Kamana kamendi

Sumeja ngiring ...

(Mojang dan jajaka saling bersahutan)

Mojang : "reksumerah"

Jajaka : "ke heula"

Mojang : "seja pasrah"

Jajaka : "mo nampa"

Mojang : "teungteuingeun

harianeun"

Jajaka : "bongan nyai"

Mojang : "kunaon"

Jajaka : "Ngalelewa"

Mojang : "kumaha"

Jajaka :"ka akang mere

tanjakan",

Mojang :'kapan biasana, rek tumanya heula, sok sumangga

abdi taros bab kawanitaan jeung

kanagaraan

pang apalna memeres mayaran hutang"

Jajaka:"Ih geuning pertentang, piraku

teu tandang,

ayu lucu mojang orde baru”

panggung sambil bergegas akan turun.)

Mojang dan jajaka: "leuleui leui leuyang"

Hayu babarengan

Cing cangkeling manuk cingklleung cineten $2 x$.

Abdi sadayana neda agung sihapunten" (sambil berjabat tangan).

\section{Pola Pertunjukan}

Sebelum para seniman atau para nayaga memulai pertunjukannya, terlebih dahulu mempersiapkan kelengkapankelengkapan yang diperlukan dalam pertunjukan, seperti mempersiapkan waditra-waditra yang akan dimainkan oleh masing-masing pemain atau nayaga.

Orang yang menyelenggarakan pertunjukan Seni Gondang atau yang punya hajat biasanya menyediakan kelengkapan-kelengkapan sebelum acara pertunjukan Seni Gondang dimulai. Dalam perlengkapan sesajen ini banyak jenis dan macamnya, seperti:

- Halu, alat pemukul lisung;

- Lisung, tempat penumbuk padi;

- Tampah, alat untuk membersihkan gabah;

- Boboko, alat untuk menyimpan beras;

- Kecapi, alat musik petik tradisonal Sunda;

- Gendang, alat musik tepuk tradisional Sunda;

- Suling, alat musik tiup tradisional Sunda; dan

- Goong, alat musik pukul tradisional Sunda.

Persiapan yang dilakukan meliputi penyesuian pakaian seragam yang akan digunakan, seperti untuk laki-laki menggunakan pakaian baju kampret warna hitam dengan menggunakan ikat kepala yang terbuat dari kain batik dan menggunakan ikat pinggang yang terbuat 
dari kain. Lain halnya dengan seragam yang dikenakan oleh wanita, biasanya menggunakan kebaya yang berwarna cerah, dilengkapi dengan kain selendang yang diikatkan pada panggul serta rambut yang dihiasi sanggul dengan sedikit hiasan yang diselipkan berupa bunga-bunga kecil, seperti bunga melati.

Setelah sore tiba para pemain mulai merias diri masing-masing, karena pada Kesenian Gondang ini biasanya para pemain saling merias satu sama lain. Namun ada juga yang merias diri sendiri, tak jarang yang menggunakan jasa perias mulai dari merias sanggul untuk wanita, make up, hingga pakaian yang akan dikenakan pada saat pertunjukan.

\section{Tempat dan Pertunjukan Kesenian Gondang Tri Buana}

1. Tempat Pertunjukan

Dalam penyajiannya Kesenian Gondang

Tri Buana biasanya dipertunjukkan atau dipergelarkan di lapangan terbuka dengan menggunakan panggung, dengan posisi para pemain berdiri berderet sambil membawa alat-alat kesenian.

2. Waktu Pertunjukan kesenian Gondang Tri Buana.

Waktu penyajian Kesenian Gondang Tri Buana biasanya pada malam hari setelah solat Isya, sekitar pukul 21.00 WIB sampai menjelang tengah malam, kira-kira pukul $24.00 \mathrm{WIB}$.

\section{Manfaat Kesenian Gondang}

Seni Gondang Tri Buana pada masyarakat Desa Nanggewer Kecamatan Pagerageung Kabupaten Tasikmalaya mempunyai manfaat sebagai sarana hiburan masyarakat. Sebagai hiburan, dalam pertunjukannya para penonton tidak terlibat secara langsung, namun penonton seringkali merasa terhibur oleh pementasan yang biasanya dalam setiap penampilan Seni Gondang Tri Buana selalu diselingi humor-humor yang bertujuan menghibur, sehingga tidak jarang menimbulkan gelak tawa pada setiap penonton yang datang.

Manfaat lainnya, yaitu sebagai penerangan, di antaranya untuk menyampaikan informasi tentang berbagai hal yang berhubungan dengan kemasyarakatan, khususnya dalam budaya pertanian dan budaya kerukunan antarmasyarakat.

Tidak kalah pentingnya untuk manfaat peringatan atau pepeling dalam Kesenian Gondang ini memiliki makna agar masyarakat senantiasa menjaga tata nilai kehidupan yang berdasar pada nilainilai keagamaan dan nilai-nilai kehidupan masyarakat.

\section{Penutup}

Kesenian Gondang merupakan kesenian tradisional yang tumbuh dan berkembang secara turun temurun dalam satu lingkungan keluarga di Desa Nanggewer. Kesenian Gondang pada mulanya bukan merupakan seni pertunjukan. Seiring dengan kemajuan pola pikir masyarakat, maka Kesenian Gondang pun mengalami perkembangan. Perkembangannya tersebut antara lain Kesenian Gondang dijadikan sarana hiburan dalam acara-acara syukuran, mapag Dewi Sri, pada acara khitanan dan pernikahan, serta saat ini Kesenian Gondang sering dipentaskan dalam acara perayaan hari kemerdekaan.

Setelah penulis mengadakan penelitian dan analisis data, maka alangkah pentingnya kesenian tradisional khususnya Kesenian Gondang, baik bagi setiap individu maupun bagi masyarakat luas untuk dikembangkan kembali dalam rangka menambah aset pariwisata yang dapat memberikan devisa bagi bangsa Indonesia. 


\section{DAFTAR PUSTAKA}

Atja. 1970.

Tjarita Ratu Pakuan. Bandung: Lembaga Bahasa dan Sejarah. 1973.

Siksa Kanda Ng Karesian. Bandung: Lembaga Kebudayaan Unpad.

1986.

Tjarita Parahijangan. Bandung: Jajasan Kebudayaan Nusalarang.

Ayatrohaedi. 1975.

"Sanghyang Siksa". Bulletin Yaperma, 8, 11, Agustus. Jakarta: Yayasan Perpustakaan Nasional.

Danasasmita, Saleh. 1973.

"Latar Belakang Sosial Sejarah Kuno Jawa Barat" Sejarah Jawa Barat. Bandung: Proyek Penunjang Peningkatan Kebudayaan Nasional Provinsi Jawa Barat. 1973.

$\mathrm{Ya} \mathrm{Nu}$ Nyusuk $\mathrm{Na}$ Pakuan. Bandung: Lembaga Kebudayaan Universitas Padjadjaran.

Djamaris, Edawar. 1977.

"Filologi dan Cara Kerja Peneliti Filolog" Bahasa dan Sastra, III, I: 20-23.
Ekadjati, S, Edi (ed). 1984.

Masyarakat Sunda dan Kebudayaannya. Jakarta: Girimukti Pasaka.

Koentjaraningrat (Ed). 1985. Manusia dan Kebudayaan Indonesia. Jakarta : Jambatan.

Kusmayati, Yetty. H, et al. 1979. Sastra Lisan Sunda Mite, Fable, dan Legenda. Jakarta: Departemen Pendidikan dan Kebudayaan. 1985

Naskah Sunda Lama di Kabupaten Cianjur. Bandung: Departemen Pendidikan dan Kebudayaan.

Sariyun,Yugo et al.1991.

Nilai Budaya dalam Permainan Rakyat Jawa Barat. Bandung: Departemen Pendidikan dan Kebudayaan.

Sediawati, Edi \& Sapardi Djoko Damono. 1983.

Seni dalam Masyarakat Indonesia, Bunga Rampai. Jakarta: Gramedia.

Suhamihardja, A. Suhandi. 1986.

Pola Hidup Masyarakat Indonesia. Bandung: Fakultas Sastra Universitas Padjadjaran. 